\title{
REALISMO CRÍTICO Y FILOSOFÍA DEL DERECHO *
}

\author{
Elías Díaz \\ Universidad Autónoma de Madrid
}

RESUMEN. En este texto E. Díaz expone las líneas básicas de su concepción de la filosofía del Derecho.

Palabras clave: E. DíAz, Estado social y democrático de Derecho, realismo crítico, legalidad, legitimidad, constitución, pensamiento español, poder social, obediencia al Derecho.

ABSTRACT. E. Díaz presents in this text the main lines of his legal philosophy conception.

Keywords: E. DíAz, Social Democratic State of Law, critical realism, legality, rule of law, legitimacy, constitution, Spanish Thought, social power, obedience to Law.

* Fecha de recepción: 28 de marzo de 2009. Fecha de aceptación: 28 de marzo de 2009. 


\section{UN BREVE ITINERARIO DE FILOSOFÍA JURÍDICA Y POLÍTICA}

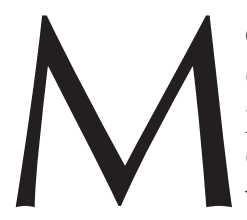

e pide el profesor M. ATIENZA que, para esta lección de investidura doctoral, hable y escriba sobre «mi filosofía del Derecho». Obedezco puntualmente al sabio amigo sin meterme antes a analizar y dilucidar, como sería debido, sobre el grado de obligatoriedad y fuerza normativa que pudiera implicar tal petición. Trataré, pues, acerca de las ideas y posiciones que - derivadas la mayor parte de ellas de los grandes y viejos maestroshaya yo ido adoptando e incorporando personalmente a mi propia responsabilidad intelectual, científica y/o filosófica. Pero se habrá de reconocer que tal rendición de cuentas de toda una vida es tarea ardua y compleja - entre la autoestima y la autocrítica一, aún más complicada, obligado como estoy a hacerlo aquí (es lógico) de manera no exigentemente expansiva sino moderadamente resumida. Son muchas cosas, vivencias y experiencias las que, con mayor densidad a esta edad, se le entrecruzan a uno con las tales teorías y filosofías, propias y ajenas.

No es, de todos modos, la primera vez que me someto a una disciplina de este introspectivo carácter. Ya lo hice en 1994, y también entonces como ahora (sospechosa coincidencia y reincidencia) gracias a la generosa instigación de los iusfilósofos de la Universidad de Alicante. Con ocasión de mi sesenta cumpleaños, su prestigiosa revista Doxa me dedicaba un número doble donde, de manera directa o indirecta, varios de los amables colegas y amigos participantes se ocupaban de unos $\mathrm{u}$ otros aspectos de esa, llamémosla así, mi filosofía del Derecho. Y acerca de ésta, entendida en sentido amplio, me interrogaban allí sin piedad los tan cercanos F. J. LAPORTA y A. RUIZ MiGUEL en una muy extensa e intensa entrevista de más de sesenta páginas estructurada en cuarenta exhaustivos e inquisitivos apartados. Ese diálogo crítico (autocrítico) me sirvió para explicarme mejor ante mí mismo — racionalizaciones a posteriori incluidas-y, a su vez, para resituar con mayor claridad la deriva prevalente, no sin discrepancias internas, entre las nuevas generaciones de los iusfilósofos hispánicos.

Pero desde entonces hasta hoy ha pasado ya algún tiempo, casi quince años desde que aquellas mis contestaciones efectivamente se escribieron. $Y$ en medio hubo otros libros y otras significativas ocasiones —así en $2002 \mathrm{mi}$ doctorado honoris causa por la Universidad Carlos III de Madrid — en que resultaba pertinente volver a tratar de estas consideraciones genéticas e identificatorias de mi filosofía jurídica, la cual en esa perspectiva - valga como rasgo definitorio - siempre ha ido vinculada a una correlativa filosofía política y también a la ineludible filosofía ética. No olvidemos, por lo demás, que nuestra «gremial» Asociación internacional y su órgano de expresión desde sus inicios unía en su misma denominación a la filosofía del Derecho con la filosofía social e, incluso con la filosofía de la economía.

Desde esas coordenadas en mi libro de 2003 Un itinerario intelectual. De filosofía jurídica y política he reunido, junto a otros dos capítulos con implicaciones asimismo de sentido autobiográfico, los textos de aquella entrevista en Doxa y de esa mencionada lección doctoral. Cabe, pues, tomar todo ello -incluso, claro está, toda mi bibliografía, donde tales dimensiones están siempre presentes en mayor o menor proporción, unidas de modo preferente a las condiciones del contexto histórico e intelectual espa- 
ñol - como base y valido precedente para estas mis reflexiones de ahora, en especial para sus inevitables lagunas e incompletas argumentaciones.

En una aproximación que sirva para caracterizar a esa filosofía jurídico-política quizás resulte conveniente comenzar, a modo de síntesis (y para cumplir con este mencionado mandato doctoral), recordando un breve elenco de los temas y posiciones que, de modo más constante y específico, están y han estado más presentes en unas u otras de mis obras. Estoy seguro de que quienes, más o menos, me conocen y me han escuchado alguna vez en conferencias, coloquios, debates, tribunales y comisiones, etc. o saben de unas u otras de mis publicaciones, incluso de mis reiteradas manías y obsesiones, no se sorprenderán en absoluto al repasar ahora conmigo esa lista selectiva de las cuestiones y las propuestas que yo mismo aduciría, sin ningún tipo de originalismo ni exclusivismo, como más propias y definitorias de mi manera de pensar en estas nuestras materias. De todos modos también resulta siempre imprescindible saber cómo le ven a uno los demás. Junto a los análisis en artículos de revistas o en monografías de más amplio espectro y las tesis doctorales de F. BAÑUls Soto y de G. AlarCón REQUEJO (aparecidas respectivamente en 2004 y 2007), de ello se han encargado últimamente, con pretexto de mi 70 cumpleaños, los trabajos de los colegas y amigos de ayer y de hoy congregados por L. HiERrO, F. LAPORTA y A. Ruiz MigueL con el resultado de la obra colectiva Revisión de Elías Díaz: sus libros y sus críticos, publicada por el Centro de Estudios Políticos y Constitucionales en asimismo 2007. De todo ello y de otras cosas más deberé intentar dar en su día, y a su altura, adecuada y matizada contestación.

Enunciaría así tales temas y programas que, ojalá con alguna positiva aportación, han sido y son preferentes espacios míos de investigación: el primero de todos — icomo no! - el Estado social y democrático de Derecho, en evolución y revisión (no siempre bien enfocada por los paradójicamente poco analíticos interpretes) desde mi ancestral libro Estado de Derecho y sociedad democrática, de 1966, hasta los más recientes como el mencionado Itinerario de 2003 . Al propio tiempo habría ahí —creo- una progresión desde el viejo pero siempre apreciado normativismo, a un actual realismo crítico: por de pronto de raíz más empírica y sociológica en cuanto a la definición/descripción del Derecho y del Estado, atendiendo y reasumiendo (no sin objeciones, como se verá), entre otros, a Kelsen, Weber, Ross, Hart, Bobbio, TReves o alguno de sus posteriores epígonos.

Una de las más decisivas implicaciones de este realismo — en el marco de un genérico positivismo metodológico y conceptual (respecto del Derecho positivo) pero siempre de carácter incluyente respecto de los valores- sería así precisamente la conexión fundamental que aquí se establece entre Derecho y poder, primero de los dos grandes temas que yo querría destacar en estas páginas. Sobre ello insistía en mi Curso de Filosofía del Derecho (publicado en 1998 recopilando algunas de las lecciones universitarias desde años muy anteriores) que, creo, resultan validas también como apoyo a las posiciones críticas contra las tendencias actuales de contumaz y empobrecedora reducción de la filosofía del Derecho a, casi exclusivamente, mera Dogmática o, como mucho, a neoformalista Teoría (General) del Derecho.

Desde esos presupuestos, legalidad y legitimidad — contando siempre en medio con la empírica, sociológica, legitimación- en procesos abiertos de clara diferenciación con interrelación, nunca fusión y confusión, serían de siempre (muy explícita- 
mente ya en mi Sociología y Filosofía del Derecho, de 1971) algunas de las categorías centrales de esa filosofía jurídico-política. Pienso en este sentido que no pocos de los prolijos y viciosos debates escolásticos de nuestros días sobre la relación (necesaria o no) entre Derecho y moral con la vista siempre puesta en la denominada «crisis del positivismo» (obviando, sin embargo, sus propias proximidades con el iusnaturalismo) en gran medida proceden precisamente de la perniciosa amalgama entre tales dimensiones éticas, sociológicas y jurídicas de legalidad, legitimidad y legitimación, o, si se prefiere, entre los propios términos hartianos de la moral legal, la moral positiva y la moral crítica.

Con frecuencia se confunden allí — con falta del buen rigor analítico- las implicaciones de la legitimidad (legalizada), incorporada en las normas jurídicas positivas, con la legitimidad social (legitimación), asumida por el grupo o por unos u otros sectores de él, y/o con la legitimidad crítica, propiamente dicha, basada en valores que exigen racional fundamentación y justificación. La denominada «moral pública» se compondría así de elementos procedentes de tales tres sectores. Recordemos, a su vez, que aquellas mencionadas ilegítimas interferencias, no sólo teóricas, también se descubren en las indagaciones sobre el proceder de jueces y demás operadores jurídicos, quizás de manera muy especial en la actual reinterpretación (DWORKIN incluido) de los viejos principios generales del Derecho.

El reconocimiento y la afirmación de las posibilidades democráticas del Derecho y del Estado (sigo, como se ve, con el mencionado resumen de mis temas y en este punto aduciría mi libro De la maldad estatal y la soberanía popular, de 1984) es otro, fundamental, puente de conexión de la filosofía jurídica con la filosofía política y la filosofía social. Incluso con las condiciones económicas, tema que («refutado MARX») práctica y teóricamente ha desaparecido —oculto el poderoso poder económico- de los programas e indagaciones neoformalistas como otra versión más del famoso «pensamiento único». Aquí se inserta (Estado democrático de Derecho) el segundo de los temas a resaltar en estas páginas. En aquel contexto, para hacer más reales esas potencialidades democráticas, se reclama hoy en buena dirección un necesario entendimiento de tales decisivas instituciones jurídico-políticas en abierta interrelación y recíproca homogeneización crítica con los denominados «nuevos movimientos sociales» (ecologismo, pacifismo, feminismo, etc.) en una mejor vertebrada y equilibrada sociedad civil. Reenviaría aquí para ambas dimensiones a mi recopilación Ética contra política de 1990: al capítulo segundo sobre la tal homogeización crítica y al capítulo primero sobre la justificación de la democracia y las implicaciones y exigencias de todo ello en la actual filosofía social, jurídica y política, en la filosofía práctica aunando siempre en ella a la filosofía moral.

Como trasfondo histórico, como válido punto de partida, incluso como base firme de estas concepciones con las que me identifico aquí, me parece del todo necesario reconocer la fuerte presencia de la cultura de la Ilustración y de sus mejores derivaciones, por supuesto que sin sacralizaciones ahistóricas y sin olvido de sus patologías e indudables insuficiencias. Pero siempre resultará insustituible el sapere aude de I. KANT: hacer libre uso público de la propia razón, salir de la minoría de edad referido a los individuos y a los pueblos, así como su propia calificación de la Ilustración como «proceso incesante en la historia de la Humanidad». No querría complicar innecesariamente 
las cosas sí recuerdo que HEGEL, enlazando con aquél, entendía ese proceso histórico como «realización de la libertad».

En cualquier caso, afirmación, pues, de la buena modernidad como estímulo para la liberación de los dogmas fundamentalistas religiosos y políticos, como lucha por el laicismo y la razón ética, como construcción de una teoría de la justicia frente a la praxis de la injusticia. A ésta, a la injusticia, le basta con vencer; en cambio, la justicia necesita además convencer. La primera sólo precisa de la fuerza, y de la ideología (mala ilustración) que la encubra, es decir del poder (económico y demás) asociado o no al Derecho. En cambio la teoría de la justicia, en su concreción histórica a través de la lucha por los derechos humanos, ha de esforzarse siempre por razonar y justificar desde el punto de vista ético (buena ilustración) su fundamento en el imprescindible y más radical valor de la dignidad humana, de su autonomía moral, expresada en la compleja y dinámica conjunción de los valores de libertad, igualdad y solidaridad (sobre la diferenciación, no siempre fácil, entre esa peor acepción de la ideología y la buena filosofía política y jurídica reenvío el capítulo final de mi libro Legalidad-legitimidad en el socialismo democrático, 1978).

Para dar pleno sentido a esas hipotéticas aportaciones de carácter más sistemático me parece, pues, imprescindible esa reivindicación del estudio y conocimiento de la historia general y, dentro de ella, de la historia de la filosofía, a la cual — puedo decir- he dedicado siempre muy amplia atención con los estudiantes en mis cursos universitarios (retraído, sin embargo, a la hora de atreverme a escribir y publicar trabajos monográficos sobre los clásicos, incluso sobre aquellos que mejor conozco). Mis concretas contribuciones a ese campo se han centrado muy preferentemente en la historia intelectual de la España contemporánea: de manera muy especial en unos u otros momentos o autores relevantes del pensamiento político, también jurídico y ético, de los siglos XIX y XX. En mi carta de trabajo, junto a dicha parte más propiamente sistemática, conceptual y hasta analítica de esas dimensiones de la filosofía de la praxis, esta parte histórica referida a nuestro país — - señalaría aquí como cierre o conclusión de este inicial resumen de materias - constituye la otra zona mía de investigación que yo siempre me he propuesto (debo advertírselo a mis críticos) como no separada sino efectivamente vinculada a la primera.

Implica esto, por un lado, la no renuncia, con carácter más o menos voluntarista, al objetivo mayor de un universalismo que casi todos invocamos pero que la razón teórica encuentra dificultades no insalvables en establecer y concordar: ahí el gran debate con el no cognoscitivismo ético. Y, por otro, que esta mi perspectiva sistemática siempre ha querido tener muy en cuenta esas condiciones históricas y sociales en las que, para bien o para menos bien, surgió y se ha ido siempre produciendo y desarrollando esa filosofía jurídica y política. De esa conexión con la Ilustración derivaba, por ejemplo, el aprecio también hacia el iusnaturalismo racional (protestante) con su vertiente en pro de los derechos humanos, frente al aquí — por tan largos tiempos-imperante iusnaturalismo teológico (católico) negador de los mismos.

En esa vía histórica figurarían mis escritos sobre la recepción — siempre pendiente y al fin lograda en la España del siglo XIX— de la Ilustración por obra de los hombres de la «Institución», con el krausismo por medio como valido pretexto, y al frente de ellos el iusfilósofo F. GINER DE LOS Ríos. De la Institución a la Constitución es el título 
de mi próximo libro, el lema que desde hace mucho vengo yo utilizando para señalar mi posición en esa historia política e intelectual, laica y civil, de un siglo de nuestro país -incluida la lucha contra la excepción dictatorial del régimen franquista- que iría simbólicamente desde la «Institución Libre de Enseñanza» (1876) a la Constitución de 1978 y su consecuente democrática derivación. Ahí estarían en el pasado mi libro de 1973 sobre la filosofía social del krausismo español o el anterior (1968) sobre el pensamiento político de UNAMUNO, el filósofo de la generación del 98, más otros ensayos referidos (generación de 1914) a ORTEGA y GASSET, J. BeSTEIRO, F. DE los Ríos, entre otros de los «viejos maestros» (libro de 1994 con ese título). De lo que (se) trataba era de la recuperación y recreación de la plural, heterodoxa y disidente historia social, política e intelectual de la España contemporánea. Es decir, de la vieja y nueva cultura liberal, democrática, socialista que en nuestros días hubo de luchar bajo/contra la doctrina dictatorial del nacional-catolicismo, en sus dos fases y versiones, la autárquica y la tecnocrática: de ello hablaba yo en mi libro de 1974 sobre el pensamiento español en la era de Franco. Se intentaba y lograba abrir así espacios de libertad que, junto con otros frentes de resistencia frente a la dictadura, harían posible la posterior consecución de la actual democracia.

\section{DEL NORMATIVISMO AL REALISMO. DERECHO Y PODER}

Es preciso situarnos, pues, en aquel ámbito y en aquel tiempo, en la España dominada por los vencedores de la guerra civil. Que en ella no era lo mismo vencer que convencer es algo de lo que ya desde el principio había avisado el Rector M. DE UNAMUNO con gran valor cívico en aquella solemne, histórica, sesión en el Paraninfo de la Universidad de Salamanca el 12 de octubre de 1936. Allí es donde de modo ineludible tenemos siempre que emplazar, al menos los de mi edad, el arranque y desarrollo de cualquiera de nuestras narraciones y reflexiones: tanto las de estricta índole personal como estas otras de carácter más intelectual y aquí hoy de filosofía jurídica y política. Siempre en la creencia de que desde (contra) esas concretas condiciones históricas y sociales haya podido salir algo más general, más universal, que pueda valer también para los demás.

La República, la democracia, la gran esperanza, doblemente traicionada por los gobiernos de su entorno, había perdido las dos guerras: coherente y solidariamente perdió primero la que a escala interna (1939) el fascismo ganó, pero contra toda justicia y razón después también perdería la que a escala internacional (1945) el fascismo perdió. Los países con regímenes totalitarios nazi-fascistas (Alemania e Italia) ayudaron decidida y decisivamente a sus correligionarios alzados en armas contra la República, mientras que los democráticos, como Estados Unidos, Inglaterra o Francia —observando sólo ellos el «pacto de no intervención»- la abandonaron por completo a su suerte, tanto en 1936-1939 como en 1945-1948. Aún reconociendo culpas y errores propios, internos, aún sabiendo de los graves problemas que aquejaban a todos los países en esos años, puede afirmarse que la responsabilidad por lo ocurrido en España también alcanzaba plenamente a Europa y por supuesto que al coloso americano. El resultado de todo aquello fue la imposición y mantenimiento en nuestro país de un régimen dictatorial —el único con Portugal en esta zona de occidente- durante casi 
cuarenta años, con diferentes fases (autárquicas y tecnocráticas) en tan largo tiempo pero siempre inspirado y justificado aquél por la ideología retrógrada antiliberal y antidemocrática del nacional-catolicismo.

Pero vayamos desde ahí a las repercusiones y cuestiones de filosofía jurídica que corresponde tratar aquí. Quienes en aquellos tiempos —en mi caso, primera mitad de los años cincuenta - éramos estudiantes de una Facultad de Derecho podíamos, en cierta medida, disponer de una mucho más especializada perspectiva para el entendimiento crítico de aquella negativa situación política: si bien desde ámbitos oficiales viniese contrarrestada con frecuencia aquella posibilidad por el dominio privilegiado en tales ámbitos jurídicos de la más tradicional y reaccionaria ideología de la ley y el orden. Ante tal alternativa es verdad que nos veríamos especialmente favorecidos en aquella Universidad de Salamanca por el magisterio, junto a otros, de los profesores J. RUIZ JiMÉNEZ y E. TIERNO GALVÁN.

Lo que estudiábamos en la Facultad era, sin duda alguna, Derecho; el mismo Derecho que se publicaba regularmente en el Boletín Oficial del Estado y explicaban los docentes de las diversas ramas de la Dogmática jurídica, la mayor parte sin graves reparos ni advertencias. Eran normas realmente dictadas desde las altas instancias gubernativas, desde un supremo e inapelable poder ejecutivo (el del Jefe del Estado que también podía ser formalmente poder legislativo) carente de todo control jurídico ni responsabilidad política ante unas fantasmales Cortes - ficticio poder legislativo-, por lo demás ambos poderes sin verdadera diferenciación ni representación democrática alguna. Y era aquel Derecho el que, hasta el final mismo del régimen —con inevitables cambios temporales que no alteraban su propia naturaleza y siempre con amplios protegidos márgenes de ilegalidad y arbitrariedad_-, utilizaban los aparatos administrativos y policiales, subordinando libertades y derechos a cualquier invocación interesada de la seguridad estatal. El mismo Derecho sin derechos - con gravísimas ausencias de ellos, en especial de los derechos humanos fundamentales- que, en definitiva, como Derecho valido interpretaban, aplicaban y hacían coercitivamente valer, es decir cumplir y hacer cumplir los jueces, el poder judicial, con la colaboración de los demás juristas y unos u otros operadores jurídicos. Si aquello era Derecho, como efectiva y válidamente lo era, todo, cualquier cosa, si se tenía el poder, resulta en consecuencia ser Derecho. Hay que señalar enseguida que, por fortuna (mejor sería decir que por «virtud»), no todos lo hacían, en estos últimos niveles, con el mismo celo, con el mismo espíritu, ni los mismos resultados negativos. Y había también, desde luego, quienes — críticos conscientes - hacían lo (im)posible por sacar de ahí las mayores y mejores conclusiones positivas para los derechos humanos y las libertades concretas.

Pero aquello era, sin duda, el Derecho, la legalidad, el Derecho positivo, el Derecho vigente, el Derecho válido: es decir — sin entrar ahora en el debate sobre tal sinonimia-, el Derecho valido que valía para que, incluso en aquella negativa situación, los ciudadanos (los súbditos) pudiesen obrar jurídicamente, para que valiesen o no sus pretensiones. El que valía para que los profesionales (jueces incluidos) tuvieran respaldo legal en sus respectivas actuaciones, el que daba o no validez a contratos, testamentos y demás negocios jurídicos o documentos públicos y privados de tal relevancia. Aquello (en cuanto legalidad) era el Derecho, aunque (en cuanto legitimidad) fuera la negación del Estado de Derecho. 
Eso era lo fundamental. Sin embargo, la ideología oficial iusnaturalista, la impuesta desde el poder de la dictadura, de modo muy especial en diversos ámbitos (planes de estudios universitarios, altas esferas administrativas y judiciales, etc.), venía en líneas generales determinada por la justificación dogmática de tal Derecho positivo —en unos interiorizada sinceramente, en otros exteriorizada oportunistamente- desde un Derecho natural, teológico y teocrático, inserto en esa tradición reaccionaria negadora de los más básicos de los derechos naturales. Para los iusnaturalistas hispánicos aquel Derecho positivo no era sólo Derecho vigente y válido sino también, reforzándolo, Derecho natural, Derecho justo, nunca por ellos cuestionado. Hoy algunos predican que ya no se sabe muy bien que es y que no es el iusnaturalismo, pero en aquellos tiempos entre nosotros lo sabíamos y lo sufríamos con toda certeza: era la ideología, teología, jurídica y política del fascismo católico y sus derivaciones. Había también en aquella situación, todo hay que decirlo, no pocos juristas prácticos y teóricos (algunos muy renombrados e influyentes) que - menospreciando privadamente a los metafísicos iusnaturalistas pero sin atreverse a negar en público aquel teocrático Derecho natural de origen divino - en el día a día actuaban de hecho como los más reductivos y acríticos positivistas que (cantera tecnocrática) para nada se planteaban ni discutían los concretos o genéricos problemas de la justicia e injusticia de tal Derecho positivo. Se «limitaban» a aceptarlo y a aplicarlo sin más.

Todo eso, reitero, era Derecho porque éste, el Derecho — sin comprometerme a dar yo aquí de él una definición definitiva y exhaustiva pero con apoyo en los que considero mejores autores clásicos y modernos- es todo sistema normativo dotado de eficaces mecanismos de coacción/sanción institucionalizada. En cualquier caso ese sería el concepto básico que yo asumiría aquí. El (mejor) Derecho es el Derecho de carácter democrático pero también es Derecho (peor) el no democrático, el dictatorial o el totalitario. El Derecho es fuerza pero es asimismo regulación del uso de la fuerza (punto de vista interno). Ahora bien, sólo puede regular eficazmente el uso de la fuerza - esto es elemental pero decisivo- quien tiene fuerza, poder, para hacerlo: y ese poder le viene al Derecho del grupo social, de los poderes sociales, de la propia sociedad a la cual aquél va después a aplicarse (punto de vista externo). Sin ese poder que de hecho radica potencialmente en la sociedad, no habría después eficaz fuerza coactiva institucionalizada en el Derecho.

Para lo que interesa aquí, se trata pues de resaltar la conexión inescindible entre Derecho y poder. Y la radicación de éste en última instancia en el poder social, que en su caso operaría ya entonces como poder constituyente. Bien entendido - esto es decisivo- que la potestas no excluye para nada la auctoritas, que las normas jurídicas no pueden borrar del mapa a las normas morales. Y que el poder constituye un fenómeno de naturaleza nada simple y lineal sino muy compleja y plural: hay agentes con gran poder, otros agentes sin poder y, como decíamos en los viejos tiempos, hay también conflictos de hegemonía y conflictos de dominación.

Esa, a su vez, necesaria referencia a la eficacia en aquella definición del Derecho significa, implica, desde luego, que el «centro de imputación» normativo y judicial funcione. Pero vinculado e incluso anterior a ello, estaría además la exigencia fáctica de un cierto relativamente amplio grado de cumplimiento y adhesión social que de hecho exige todo Derecho. Esta es, digamos, la normalidad del sistema normativo. Hay que 
advertir enseguida que tal adhesión y conformidad, tal legitimación, puede ser lograda por unos u otros no equiparables motivos, por unas u otras razones o sinrazones, por unas u otras vías: de las cuales sin embargo - pero esa es ya otra cuestión - la más justa y la más eficaz es la que procede de la interna y ética, consciente y libre aceptación por los ciudadanos. Estos dos niveles de legitimación, o deslegitimación, sobre los que enseguida volveremos, funcionan todavía dentro del cuadro que podríamos denominar como «poder constituido», es decir dentro del marco del Derecho que se presenta como válido. Como puede verse, este «punto de vista interno» está — creomás cercano al correspondiente de HART; en cambio, en el «punto de vista externo» se alude a cosas diferentes: aquél al punto de vista del observador y del científico; yo a la interrelación social con el Derecho, e incluso más por tanto al «poder constituyente».

El genérico respeto de instituciones, jueces y ciudadanos a la ley, al Derecho, al ordenamiento jurídico en su conjunto, como sistema normativo, constituye así condición necesaria (y bien entendida, es decir bien promulgada, creo que también razón suficiente) para su validez. Respetar la ley significa acatarla, obedecerla, cumplirla. La evasiva tradicional «se acata pero no se cumple» no es más que una añagaza o pretexto formalista para en realidad no respetar, ni tampoco acatar la ley. Todo lo más, dicho alegato tradicional significaría que se reconoce que existe como vigente esa ley (se acata) pero que no se aplica (no se cumple). Ahora bien, si las leyes no se cumplen, si no se aplican, si no tienen por tanto ninguna eficacia, entonces el resultado y la consecuencia es que ni se acatan, ni se hacen valer, ni valen, ni por tanto - aunque promulgadas y vigentes - poseen propiamente auténtica validez. Respecto de ésta hago observar, para los sabios colegas, que se trata, pues, aquí de un concepto empírico (realista) de validez: un concepto de posible ley válida o inválida (según se respete por ciudadanos y jueces), diferente de la segunda noción normativa de validez material, plena y sustantiva (no exclusivamente de vigencia formal) propuesta, entre otros, por L. FERRAJOLI. La de éste — creo- permanece en el interior del sistema jurídico; la aquí propuesta reenvía más el contraste con la realidad social. En definitiva yo haría míos los consejos y raciocinios que el gran don Quijote le invocaba a su fiel Sancho sobre la observancia de órdenes y pragmáticas para el buen gobierno de éste en la soñada ínsula Barataria, puntualizando «que las pragmáticas que no se guardan lo mismo es que si no lo fuesen» (como exhortaba con este texto en uno de sus últimos libros el recordado amigo L. García SAN Miguel).

Recupero de nuevo la línea general de estas aseveraciones, diferenciando tres principales planos o niveles de esa relación — de normalidad y de anormalidad- entre eficacia y validez, de esa ineludible conexión entre Derecho y poder, que en última instancia llevaría ya desde el ámbito del poder constituido al más decisorio del poder constituyente (resultará valida y eficaz para estas cuestiones la lectura, entre otras, de la rigurosa obra de L. HieRRO, La eficacia de las normas jurídicas, 2003, con la muy seleccionada bibliografía allí incluida). Serían, pues, aquellas tres decisivas zonas las siguientes.

a) La eficacia, el cumplimiento, el respeto a las leyes implica —ya lo veíamoscomo primer nivel, como base, la implícita adhesión, la genérica obediencia, la actuación conforme a ellas por los ciudadanos, es decir por los sujetos primariamente destinatarios de ese ordenamiento jurídico, incluso la libre y voluntaria aceptación 
compatible por lo demás con un relativo grado de desobediencias e infracciones individuales. Esa actitud positiva de los ciudadanos aporta así legitimación y una mayor y más fuerte validez a la legalidad. El Derecho, por lo tanto, interesa remarcarlo, no es sólo ni esencialmente el momento patológico del conflicto y de la decisión judicial (A. Ross y las teorías «realistas» judicialistas). Antes y al lado de él está siempre el mayor o menor cumplimiento fáctico, expreso y cotidiano por los ciudadanos de la mayor parte de las normas jurídicas: primacía, pues, del momento normativo, del normativismo.

b) Pero, eso sí, la violación, el incumplimiento, por parte de ellos de unas u otras normas concretas pone en eficaz acción al aparato judicial — segundo nivel—a fin de restaurar, suele decirse, el Derecho (objetivo), el orden jurídico quebrantado y, con ello, reintegrar/compensar los derechos subjetivos (bienes materiales o inmateriales) con tal incumplimiento amenazados o conculcados. La eficaz acción de los jueces, de los operadores jurídicos, el respeto de ellos a las leyes, a las normas (reglas y principios, DWORKIN), añade así legitimación y reconstruye, pues, la concreta falta de respeto, el no cumplimiento específico de unas u otras normas por parte de unos u otros ciudadanos. El Derecho (HART) son normas primarias pero también secundarias, establecimiento de derechos y deberes, más el trabajo adjudicado a los operadores jurídicos dentro del marco jurídico reconocido. E, incluso, otras construcciones y prácticas derivadas de la coherente autonomía de la voluntad o de la propia autonormación social podrían formar también parte subordinada del sistema jurídico dotado de validez.

Es obvio, no obstante, que si aquel incumplimiento ciudadano creciera en grandes proporciones (difícil establecer la frontera), si ese rechazo tendiera a generalizarse, la propia acción de los jueces se dificultaría en muy alta medida. Más aún si ellos mismos — que también son ciudadanos- se viesen al propio tiempo afectados, tentados o forzados (por unas u otras, buenas o malas, razones y/o motivaciones) a no aplicar ese Derecho, o muchas de sus disposiciones. Tales situaciones no son, desde luego, habituales pero tampoco irreales (rebeldía judicial, revolución anti-institucional, etc.): como situación límite reenvían, en cualquier caso, a los análisis de fondo sobre la cuestión. En ellas - que incluirían en el desistimiento a las superiores instancias de la magistratura- es cuando entonces ese sistema u ordenamiento jurídico válidamente constituido, esa legalidad normativa perdería toda legitimación fáctica y cuando, como resultado, esas leyes carentes de eficacia (cívica y judicial) verían puesta en cuestión su propia validez. Los (mis, tus) hipotéticos derechos no (me, te) valdrían, ni las (mis, tus) garantías de protección tampoco valdrían, no tendrían validez, si los demás conciudadanos no los respetan y si los jueces —última cláusula interna de cierre- no actúan ni hacen nada para hacerlos respetar. Esas normas dejarían de ser en rigor normas jurídicas, es decir — ese es su principal sentido diferenciador en relación con la moral— dejarían de ser normas dotadas de un poder de coacción/sanción institucionalizada. ¿Qué, cuál, sería la validez de un ordenamiento jurídico que no tuviera poder para hacerse valer entre los ciudadanos y los aparatos jurisdiccionales?

A propósito de tales cuestiones H. KELSEN señalaba - recuérdese- que las ciencias empíricas (naturales y sociales, con otras diferencias entre ellas) responden y se estructuran a través del principio de causalidad (si $p$, causa, es, se produce $q$, efecto), mientras que las ciencias normativas (entre ellas el Derecho y, desde ahí, la ciencia jurídica) lo hacen a través del principio de imputación (si $p$, debe ser $q$, más concretamente 
si $p$, norma, debe ser - o producirse $-q$, como consecuencia de su aplicación). Respectivamente, por tanto, proposiciones en indicativo y proposiciones en imperativo. Ahora bien —categoría diferencial — en el Derecho tal consecuencia y esto es decisivo no se produce de manera automática: alguien, el poder judicial como «centro de imputación», es quien - junto con los demás operadores- debe hacer, frente al que trata de impedirlo, que la norma produzca efectivamente sus efectos. Incluso en caso de cumplimiento ciudadano la mayor seguridad hace intervenir a unos u otros operadores jurídicos institucionales. No hay, pues, en el Derecho una causalidad directa, mecánica, inmediata: hacen falta mediadores. No funciona ahí el principio de causalidad sino el principio de imputación. Se trata, eso sí, en tal imputación de un deber hipotético, jurídico, condicional, no de un deber categórico, apodíctico, moral.

En tal concepción, «teoría pura del Derecho» la denominó su autor, no tan pura, por fortuna más contaminada/comunicada con lo fáctico, según mi interpretación (tendría que pedir disculpas a los ilustres estudiosos de KELSEN por este breve resumen de tan compleja y debatida posición), la Grundnorm, norma fundamental kelseniana como norma de carácter lógico-trascendental, norma hipotética, y norma no positiva sino sobrepuesta al Derecho puesto, positum, positivo, vendría a poder reformularse en los siguientes términos: se debe (o debes) obedecer a la Constitución para (a fin de) que tenga validez el ordenamiento jurídico. Es decir, debes obedecer a la Constitución si quieres que tus actos (contratos, testamentos, demandas judiciales, etc.) y tus derechos valgan, sean válidos, tengan validez. Si por los motivos que fueren (por la mencionada resistencia judicial o por una revolución político-social) el «centro de imputación» se cierra o no funciona, ese Derecho deja de valer, incluso a pesar de la obediencia a él por los ciudadanos: carente de eficacia (judicial) pierde su validez (normativa). O, al menos, está en grave trance de perderla. Como se ve, algo de (autolimitado) «realismo» había y hay en el «judicialismo» aunque no tanto como para poder entre ellos considerarse sinónimos.

Pero — sigue abierta la cuestión — también en el Derecho, o diríamos que de manera muy relevante en el Derecho, existe el horror al vacío. En este tipo de análisis que yo califico como realismo crítico, sin embargo los jueces, el judicialismo, no son —ya se ha dicho antes- la exclusiva legalidad, la única y última realidad. Si amplias mayorías de ciudadanos no cumplen, no respetan, esas leyes, si los jueces (operadores jurídicos) en sus más elevadas, supremas, instancias a su vez no las aplican, tampoco las respetan, habrán de ser los otros poderes institucionales (legislativo y ejecutivo/administrativo) quienes intervengan, siempre con el apoyo de los poderes sociales que todavía puedan tener detrás, para dar eficaz solución a esa (casi límite, compleja y delicada) situación que lo es de recuperación del Derecho y de su validez. Y ello podrá llevarse a cabo, o bien - muy difícil tarea en esta hipótesis- forzando con los correspondientes aparatos estatales a unos (ciudadanos) y a otros (jueces) a cumplirlas y aplicarlas, o bien - más efectivo, con mayor legitimación — yendo hacia un cambio controlado, según oportuna cadencia, de ese Derecho tan rechazado, orientándolo desde pautas y criterios demandados, exigidos con mayor o menor fuerza, por el grupo social. Por supuesto que en ese rechazo (o en la aceptación) por jueces y ciudadanos pueden o no concurrir tanto razones de legítima oportunidad política como razones de estricta conciencia ética individual. 
c) Pero si esas dos mencionadas vías de acción fracasan estaríamos ya, evitado el caos, en el central tema kelseniano de la revolución. Así — tercer y más radical nivel de soporte, protección y seguridad para el Derecho-, será en definitiva ese poder social, con toda su plural complejidad, quien impulsando al (viejo o nuevo) poder institucional en favor de otras leyes, de otro ordenamiento jurídico, incluso actuando como verdadero poder constituyente, proporcionará a la (nueva) legalidad una mayor legitimación, es decir una mayor adhesión, cumplimiento y aplicación: y con ello — desde esta perspectiva para la identificación del Derecho- también una más efectiva y auténtica validez. Advirtamos, una vez más, que — sin posible confusión de planos- para nada resultara indiferente a esas categorías definitorias del Derecho (validez/legalidad y eficacia/legitimación) la dimensión crítica valorativa de la legitimidad ética y política, de la teoría y práctica de la justicia, de su justificación.

\section{EL HECHO Y EL DERECHO. EFICACIA Y VALIDEZ. ¿POR QUÉ OBEDECER?}

Es, como se sabe, el propio KeLSEN quien tratando en su Teoría general del Derecho y del Estado de «la norma básica de un orden jurídico» y, más en concreto, sobre el «cambio de la norma básica», reintroduce la cuestión de la «revolución» (no necesariamente violenta) que en su análisis es, me parece, fundamental para la íntima conexión en que aquí estamos entre Derecho y poder. Establece así aquél de modo decisivo, es decir de modo directo y no colateral, en el arranque mismo de tal análisis (son textos bien conocidos y que adopto como los de mayor interés para nuestro tema): «Precisamente el fenómeno de la revolución descubre con toda claridad la significación de la norma básica». No se trata, pues, de una cuestión secundaria, coyuntural, sino de algo que incide radicalmente en el núcleo duro de lo que es el Derecho.

Los términos en que se expresa KELSEN son suficientemente claros, pero mostrando - creo- a su vez algunas de las limitaciones e insuficiencias de la «teoría pura del Derecho»: la validez de las normas jurídicas — queda establecido en ella— se encuentra determinada únicamente por «el orden al cual las normas pertenecen. Permanecen válidas mientras no son derogadas en la forma que el mismo orden jurídico determine». Pero añade enseguida aquél, que «sin embargo tal principio únicamente vale en determinadas circunstancias. Deja de valer en el caso de una revolución, entendida esa palabra en su sentido más general» (que englobaría también los «golpes de Estado» sean de un signo o de otro). Esas determinadas circunstancias válidas lo serían, puede decirse, de tejas abajo de la pirámide y para situaciones de normalidad y básica estabilidad. Ahí el normativismo kelseniano y el de sus derivados funciona en líneas generales satisfactoriamente y de él nos hemos beneficiado siempre con gratitud juristas, filósofos del Derecho y todos los ciudadanos.

El problema es de si de tejas arriba (pero no sin repercusiones hacia abajo), es decir buscando el soporte coherente de la norma básica (Grundnorm), podrá también resultar convincente su invariable aserto de que «la razón o fundamento de validez de una norma está siempre en otra norma y no en un hecho»; o que «la eficacia es condición de la validez, pero no la razón de la misma. Una norma - dice KeLSEN- 
no es válida porque es eficaz; es válida si el orden al cual pertenece tiene, en general, eficacia». Pero ahí precisamente, respecto de esa eficacia general, es donde -traída por él- incide con todo su vigor la cuestión de la revolución entendida como cambio de orden jurídico cuando la sustitución — esto es lo decisivo para aquél一 no se hace en la forma prevista y prescrita por el orden anterior. Puede que sea o no por medio de la fuerza, admitiría en principio KELSEN, aunque con más frecuencia se refiere a ella como unida a la violencia: en tal situación, pero no sólo en ella, es donde quizás se descubre con mayor nitidez la sustancial relación entre Derecho y poder.

No es, parece, muy habitual que una revolución cambie de orden jurídico haciéndolo en la forma prevista y prescrita por el orden jurídico-político anterior. Se califique o no de revolución, un buen ejemplo de cambio profundo habría sido en España el advenimiento y proclamación de la segunda República en 1931. En este mismo sentido hago aquí este brevísimo inciso para señalar que, en coherencia con estos y otros parámetros, la transición española a la democracia y la propia Constitución de 1978, al proceder formalmente (no tanto realmente) de la anterior ley para la reforma política — «de la norma a la norma», quedó dicho—, no habría sido (¡admitámoslo!) una revolución; pero si una muy profunda «reforma para la ruptura» - hecho social, presión popular - que, sin embargo, habría derribado las bases jurídicas y políticas (no tanto las sociales y económicas) del precedente orden dictatorial.

La revolución establece un nuevo Derecho, una nueva Constitución sin que, en los términos de KELSEN, el nuevo orden jurídico se haya producido y establecido según la forma prevista y prescrita por el orden anterior. Es, pues, el hecho de la revolución, no las viejas normas, quien va a crear y dar validez a las nuevas normas. El poder de la revolución es quien va a hacer que esas nuevas normas valgan, tengan validez. Ello, desde luego, no concuerda para nada con la «teoría pura» de aquél — de norma a nor$\mathrm{ma}$, no de hecho a norma- (ni con otras tajantes escisiones entre ser y deber ser) pero creo que tampoco concuerda mucho con dicha teoría lo que, no sin ambigüedades de fondo, él mismo se ve casi obligado a reconocer. Recordaré sólo algunos de los textos de KELSEN en este sentido, remarcando de todos modos que no estoy proponiéndome aquí una más certera reinterpretación de aquél sino únicamente su hipotética relectura para esa substancial relación entre Derecho y poder. «Desde el punto de vista jurídico, el criterio decisivo de una revolución —señala siempre KELSEN- es que el orden en vigor es derrocado y reemplazado por un orden nuevo en una forma no prevista por el anterior. Comúnmente - hace también observar- los nuevos hombres a quienes la revolución lleva al poder únicamente anulan la Constitución y ciertas leyes de significación política superior, poniendo en su lugar otras normas. Una gran parte del viejo orden jurídico «permanece» válida, incluso dentro del marco del nuevo orden. Pero la frase «permanece válida» — advierte KELSEN respecto de este supuesto— no ofrece una descripción adecuada del fenómeno. Únicamente los contenidos de tales normas son los que no cambian, no - esta que pongo en cursivas es la expresión exacta de aquél- su razón de validez. Dejan de ser válidas en virtud de haber sido creadas en la forma prescrita por la vieja Constitución (...) Si ciertas leyes promulgadas bajo el imperio de la vieja Constitución «continúan siendo válidas» bajo la Constitución nueva, ello únicamente es posible porque la nueva Constitución —insiste- les confiere validez, ya expresa ya tácitamente». 
Terminaría con algunas últimas palabras y reflexiones suyas, de —si cabe- aún mayor contundencia: «Ello revela cómo todas las normas del viejo orden son privadas de su validez — dice- por el movimiento revolucionario, en forma que no concuerda con el principio de legitimidad. Y tales normas no pierden su validez únicamente de facto, sino también de iure [advierto que estas cursivas son asimismo del propio KELSEN]. Ningún jurista sostendría que incluso después de una revolución victoriosa la vieja Constitución y las leyes fundadas en ésta permanecen en vigor, por el hecho de no haber sido abrogadas en la forma establecida por el orden precedente. Todo jurista habrá de presumir que el viejo orden —al cual ya no corresponde realidad política ninguna - ha dejado de ser válido, y que todas las normas que tienen validez dentro del nuevo, reciben ésta en forma exclusiva de la nueva Constitución. De lo anterior se sigue, desde el punto de vista jurídico, que las del viejo orden no pueden ya reputarse como válidas». La verdad es que ante las tan poderosas razones alegadas por el mismísimo KELSEN se comprende que después no le habría de resultar nada fácil seguir diferenciando con tanta radicalidad entre condición (que de hecho se convierte en imprescindible) y razón de la validez. Desde otro punto de vista — cuestionada la razónno faltará quien diga que ni una ni otra serían hoy quizás absolutamente suficientes. A. CALSAMIGLIA dejó bien apuntado, entre nosotros, como tales limitaciones kelsenianas aparecen en otros diferentes momentos de todo sistema jurídico.

Aunque en estas cuestiones aquél siempre permaneciera invariablemente fiel a los postulados de su teoría pura («la razón o fundamento de validez de una norma está siempre en otra norma, nunca en un hecho») o, incluso, quisiera entender de diferente modo esos u otros textos sobre el hecho de la revolución, a mi juicio a partir y en base de esos planteamientos suyos pueden muy bien obtenerse importantes apoyos directos e indirectos para esa substancial conexión entre Derecho y poder: en definitiva, entre el hecho del poder y el hecho del Derecho, aunque este se exprese en normas. De esto — reitero- es de lo que se trata aquí, de resaltar más esa inseparable relación y no - lejos de mis aspiraciones- de fijar doctrina alguna sobre el gran KELSEN. No pretendo responsabilizarle de mis propias argumentaciones y conclusiones. Lo que yo aquí señalaría es que la norma básica según la cual se debe obedecer la Constitución para que el ordenamiento jurídico tenga validez implica ya, según no pocos intérpretes, el reenvío ineludible a un substrato fáctico: al hecho de la necesaria obediencia a aquélla, al hecho de un necesario consenso (consentimiento) o, de manera ya más directa y decisiva, al hecho de la obediencia sin más a las determinaciones del poder -legítimo o ilegítimo- que precisamente haya logrado dotar de eficacia social y judicial a sus normas jurídicas. El hecho pues como substrato de la norma: del poder como hecho a la norma como hecho (como un «ser» que impone un «deber ser»). Es decir, del normativismo al realismo crítico, pero ambos en conexión y evitando otros acríticos «realismos».

La Grundnorm según la cual debes obedecer la Constitución, debes considerarla válida si quieres que tus actos valgan jurídicamente, si quieres que tus actos tengan validez, se resuelve siempre en última instancia en la norma básica según la cual debes obedecer la Constitución y las normas jurídicas que de hecho logran hacer que tus actos valgan (y ello, como veíamos, se advierte con mayor rotundidad al tratar del hecho que supone un cambio revolucionario). Es decir, debes obedecer la Constitución y 
las normas que precisamente tienen la fuerza, el poder (institucional y social) capaces - como quieres- de proteger con eficacia tus acciones y pretensiones, tus derechos. Para tener derechos tienes que reconocer al Derecho. Jurídicamente (otra cosa es la ética) debes, pues, obedecer a quien de hecho tiene el poder de hacerlos efectivos, de hacerlos respetar. Ese sería el significado real (realista) de la validez. Si la vieja Constitución ya no tiene tras de sí la fuerza, el poder, será la nueva Constitución, con fuerza, con poder, la que kelsenianamente se habrá de obedecer. Eso es lo que, a mi juicio, otorga validez (y no mera vigencia y existencia) al Derecho. Con KeLSEN (a pesar de KELSEN) se puede llegar, como se ve, a los aledaños mismos del poder. Y H. HeLLER, por su parte, señalará que Derecho y poder son dos caras de la misma moneda, dos realidades inseparables.

Obedecer al Derecho es, en definitiva, obedecer al poder: al que legisla, al que puede legislar, y al que puede hacer que en concreto mis actos valgan jurídicamente. $\mathrm{O}$ en otros términos, el Derecho es el poder y las determinaciones de él: «hecho fundante básico» lo denomina, desde KELSEN hacia HELLER, pero más referido al poder institucional que al poder social, G. PECES-BARBA. Vinculando ambas dimensiones, a mi juicio con base más radical en la segunda de ellas, esa decisiva presencia del poder (de los poderes resultantes de sus complejas interrelaciones) es algo que se muestra tanto en su expresión procedimental como en sus contenidos materiales. Se puede muy bien asumir con FOUCAULT que el poder penetra de modo profundo - microfísica del poder - en toda la red de la sociedad.

Pero entendido así «more realista» el Derecho, lo que también enseguida resulta fundamental destacar, con elemental uso de la polisemia, es que el Derecho válido (ciencia del Derecho) no vale para lo mismo (sociología del Derecho) ni vale lo mismo (filosofía del Derecho). Y que la legalidad implica coherentes y diferentes interrelaciones (aludidas al principio de estas páginas) con la legitimación y con la legitimidad, por utilizar mis habituales denominaciones. Hay poderes sociales y ordenamientos jurídicos a los que cabe reconocer mayor legitimidad (crítica) y otros del todo ilegítimos donde no existen los mínimos controles para evitar el abuso y la arbitrariedad, la prepotencia del poder y la negación de los derechos humanos. Es decir, hay poderes y ordenamientos jurídicos más concordes con la justicia (derivada, a mi juicio, de la libertad, la igualdad y la solidaridad) y otros que, en diferentes graduaciones, se podrían sin duda calificar de injustos. Para mayor claridad semántica y conceptual, pero sin inamovible rigidez, se puede adscribir el término legitimidad a la filosofía política y el de justicia a la filosofía moral. Y ambos con diferenciada aplicación a la filosofía jurídica.

En otro orden de cosas, no estaría de más señalar que una teoría del Derecho como la que, sólo a muy grandes rasgos, se viene pergeñando aquí desde la perspectiva del «realismo crítico» y la substancial vinculación entre Derecho y poder (parte primera de la filosofía jurídico-política, la segunda sería la teoría de la legitimidad y de la justicia), habría de tener - por supuesto- un específico desarrollo en concretos y consecuentes programas docentes y de investigación. Serían en buena medida diferentes (más amplios) de los que, por un lado, se prefieren hoy desde ciertas perspectivas neoformalistas de varia conformación y más aún, por otro, desde los enfoques y presupuestos provenientes de unas u otras doctrinas de carácter iusnaturalista. 
Me referiré, como símbolo, a una sola cuestión en cada uno de esos sectores. La primera para resaltar que esa teoría (realista) del Derecho podría y debería seguir tratando, por supuesto, la mayoría de los temas actuales de carácter más interno, científico jurídico, pero incorporado otros, hoy menos frecuentes pero muy necesarios, de carácter más histórico y sociológico: así en la relación Derecho-poder poniendo de manifiesto la complejidad de éste (y de aquél), diferenciando por ejemplo entre agentes con gran poder (económico-mediático, etc.) y agentes sin poder (minorías marginadas, etc.), así como su tan desigual presencia en el mundo del Derecho. Con la sociología del Derecho — casi del todo ausente en nuestros planes de estudio — se vería por ejemplo con mayor nitidez que argumentar sobre el Derecho, es también argumentar sobre el poder y que si el Derecho racionaliza a la sociedad, también racionaliza al poder. La segunda para clarificar —entre otras cosas_ a qué tipo de moral se alude cuando se habla hoy de la crisis del positivismo jurídico y de, por el contrario, la relación necesaria entre aquélla y el Derecho. $\mathrm{Y}$ algo parecido ocurre respecto de los principios que, se señala, deben aplicar jueces y operadores: ¿se trata de la moral positiva legal (legitimidad legalizada incluida la constitucional), de la moral positiva social (legitimidad eficaz), de la moral (o legitimidad) crítica? A mi juicio, en algunas importantes posiciones actuales esto no queda, con frecuencia, ni medianamente claro y es fuente constante de graves confusiones.

Desde tal perspectiva realista resulta de todo punto necesario volver siempre a recordar — en una a modo de recapitulación sectorial — que legitimación es un concepto de base empírica, un resultado fáctico de aceptación y seguimiento social referido a una determinada legalidad, a un concreto ordenamiento jurídico e institucional, y también a una $u$ otra perspectiva de legitimidad, a uno u otro sistema de valores. Pero - esto es decisivo- en cuanto tal resultado fáctico, tal legitimación puede lograrse por muy diferentes, pero no indiferentes, vías: por las de la autonomía moral, el convencimiento y la argumentación racional, es decir la libre decisión y participación (a mi juicio, sin duda, las vías más legítimas) pero también por las del engaño, la corrupción o, incluso, el terror (ilegítimas e injustas en diversidad de escalas y, por desgracia, a veces, en parcial convivencia con las del modelo anterior). Resulta, pues, evidente que esos diferentes modos fácticos de legitimación con tan graves connotaciones no pueden, ni deben, substraerse a la crítica, al juicio de valor de esas no indiferentes concepciones de la legitimidad.

Haría observar asimismo aquí, sin entrar ahora en mayores disquisiciones, que a mi juicio en WEBER la creencia social en la legitimidad de una legalidad es todavía propiamente legitimación; otra cosa es que su modelo de legitimidad legal-racional fuese quien en el mundo moderno encontrase mayor legitimación precisamente por ser —así lo creo también yo— más legítimo, más justo, por avanzar no sólo en eficacia y previsión sino sobre todo y principalmente en autonomía personal y participación real. El «realismo crítico» aquí defendido no es pues, en cuanto tal, conformismo indiferenciado y acrítico respecto de uno u otro poder: podría ir así de verdad más allá de los viejos iusnaturalismos, especialmente del iusnaturalismo teocrático, pero también de los menos viejos reductivos y excluyentes iuspositivismos, especialmente del positivismo tecnocrático.

En virtud de todo ello habría — creo- otra conclusión de lo reseñado hasta aquí: que el respeto a la ley, que incluye obediencia, su legitimación que es la base 
de su legalidad (realismo), exige — también por coherencia interna- plantear los problemas de fondo de la legitimidad, estos que son más propios y específicos de la filosofía jurídica y política (realismo crítico). Y ello porque todo sistema de legalidad/legitimación lleva dentro de sí uno u otro sistema de legitimidad. Se trata, en síntesis, de determinar cuándo y en qué condiciones merece de verdad la ley el respeto de todos y cada uno de los ciudadanos. Eso empieza a ocurrir a mi juicio - base fundamental - cuando estos con autonomía moral pueden realmente participar y decidir en libertad. El imperio de la ley así producida y el consecuente respeto a los derechos humanos allí implicados constituyen, a mi juicio, el más respetable —pero no inapelable - criterio (ético) de legitimidad y de su derivado sistema de legalidad: a ello es a lo que yo vengo desde siempre denominando Estado social y democrático de Derecho.

\section{ESTADO DEMOCRÁTICO DE DERECHO. CONSTITUCIÓN Y LEGISLACIÓN}

Hemos hablado hasta aquí del Derecho y del poder. Ahora — precisamente por reconocida esa su íntima e interna relación — habría ineludiblemente que indagar sobre cómo puedan hacerse ambos más legítimos y más justos (incluso desde ahí más operativos y eficaces) empezando por considerar para ello los medios e instrumentos normativos e institucionales de que disponemos. No todo Derecho ni todo poder incorpora y simboliza el mismo grado de justicia (o injusticia) y de legitimidad (o ilegitimidad). Se podría decir que, en definitiva, se trata de diferenciar entre poder con (como) legalidad y poder con (como) legitimidad, o sea entre potestas y auctoritas, entre - con WEBERMacht y Herrschaft.

En Fragmentos para una teoría de la Constitución, obra de 2007 en la que sus tres autores, J. Aguiló Regla, M. Atienza y J. Ruiz Manero «parten — dicen- de los mismos presupuestos teóricos y persiguen una misma meta», se puntualiza para una válida iniciación de este tema que el rótulo «Estado constitucional, obviamente, quiere decir algo distinto a Estado en el que está vigente una Constitución». Y, apoyándose en BOVERO, añade así concretamente M. ATIENZA, autor del capítulo donde va esa afirmación que comparto y donde Constitución equivaldría a ordenamiento jurídico, a Derecho sin más en su área más general e incluso fundamental: «Constitución, en su sentido más amplio, hace referencia a la estructura de un organismo político, de un Estado: al diseño y organización de los poderes de decisión colectiva de una comunidad; así entendida ( $\mathrm{y}$ - recuerda - así es como entiende el término, por ejemplo, KELSEN) cualquier Estado o unidad política tendría una Constitución. Pero - a partir de ahí precisa enseguida ATIENZA- en un sentido más estricto tal y como la expresión suele usarse en la época contemporánea, una Constitución supone dos requisitos más: una declaración de derechos y una organización inspirada en cierta interpretación del principio de separación de poderes». Es casi literal —recuérdese- el art. 16 de la Declaración de derechos del hombre y del ciudadano de la revolución francesa de 1789: «Toda sociedad en la cual la garantía de los derechos no está asegurada, ni la separación de poderes determinada, carece de Constitución». 
En un muy antiguo artículo mío, de 1968 en Cuadernos para el Diálogo, sobre esta histórica importantísima Declaración de derechos (después tal trabajo ampliado y recopilado en 1978 en mi ya mencionado libro Legalidad-legitimidad en el socialismo democrático) ya acogía yo esa misma diferenciación subrayando que, si bien todo Estado tiene una - con minúscula - constitución material, la que sea, en cambio en sentido estricto y formal el término Constitución habría de entenderse como sinónimo de Estado constitucional o, si se prefiere - decía yo allí — como sinónimo de Estado de Derecho. Es decir, como escribe aquí ATIENZA, que «todo Estado o unidad política tendría una Constitución» pero que no todo Estado sería Estado constitucional. Hablando de mi filosofía jurídica — como se me ha ordenado precisamente por él— no puedo por menos de rememorar una vez más el invariable comienzo de aquél mi primer libro en las muy especiales circunstancias de 1966: «No todo Estado es Estado de Derecho». Y seguía allí: «Por supuesto, es cierto que todo Estado crea y utiliza un Derecho, que todo Estado funciona con un sistema normativo jurídico (...) Y, sin embargo, decimos, no todo Estado es Estado de Derecho; la existencia de un orden jurídico, de un sistema de legalidad, no autoriza a hablar sin más de Estado de Derecho. Designar como tal a todo Estado, por el simple hecho de que se sirve de un sistema normativo jurídico, constituye una imprecisión conceptual y real que sólo lleva - a veces intencionadamente-al confusionismo». Lo mismo podría decirse de manera casi redundante, ayer y hoy, respecto del Estado constitucional.

En la trastienda política de esta cuestión en nuestro país en aquellos complicados tiempos — lo recuerdo para los menos «historicistas» de los más jóvenes, pero también para los más «ahistoricistas» de los menos jóvenes - estaba el famoso informe sobre $E l$ imperio de la ley en España que la Comisión Internacional de Juristas había preparado y editado en su sede de Ginebra en 1962 (pero aquí distribuido clandestinamente) donde quedaba bien claro y probado lo evidente: que el régimen de Franco no era para nada un Estado de Derecho, como contumaz e inútilmente se pretendía en la réplica oficial España, Estado de Derecho, redactada y ampliamente difundida (1964) por el Servicio Informativo Español del correspondiente Ministerio dirigido a la sazón por el catedrático de Derecho Político M. Fraga IrIBARne. En aquel mismo año de 1962, en febrero, el gobierno español se había atrevido a solicitar formalmente su «posible vinculación» con la Comunidad Económica Europea «susceptible —se decía allí_ de llegar en su día a la plena integración», petición que durante todo el periodo franquista fue siempre diplomáticamente aplazada (denegada) por incumplimiento de los mínimos democráticos exigidos. Así se ponía de manifiesto en el documento producido por buena parte de la oposición política española del exilio y del interior reunida en Munich en junio de 1962 (el famoso «contubernio»).

En este contexto y a propósito de tales debates académicos y políticos, en algunos trabajos míos publicados desde 1963 yo venía insistiendo en las exigencias que la ciencia jurídica europea consideraba propias del Estado de Derecho, notas que después quedaban asumidas en mi ya mencionado Estado de Derecho y sociedad democrática (de 1966) libro que fue inmediatamente secuestrado por orden del Ministerio de Información. Yo no hablaba allí expresamente de España, sólo señalaba lo que, a mi juicio, desde posiciones democráticas era y debía ser aquél, por lo que el Tribunal de Orden Público finalmente tuvo que autorizar su pública distribución y circulación. Parecía, 
en efecto, un tanto extraño e incongruente que se secuestrara y prohibiera un libro sobre el Estado de Derecho en un país cuyo gobierno precisamente pretendía encontrar legitimación internacional para él como un Estado de Derecho ( ${ }_{\text {SSeñal indeleble tal }}$ autorización judicial, y otras actuaciones similares, de que estábamos ya en un Estado de Derecho!, gritaban alborozados los reducionistas de este y/o los modernizadores del régimen). Pero es cierto que yo también describía y criticaba allí las doctrinas jurídicas y políticas que habían inspirado y sostenido a los Estados totalitarios del nazismo alemán y del fascismo italiano. Para el Estado español de los años sesenta resultaba insoportable que, incluso alegando el desarrollismo tecnocrático, no se le reconociera por lo que inútil e infundadamente por entonces simulaba ser: un Estado constitucional y un Estado de Derecho; y que, además, se le recordaran doctrinas y actitudes en muy amplia medida coincidentes con lo que él mismo expresamente había sido hasta pocos años antes, pero todavía con base para que se le pudiera identificar con lo que inútilmente por entonces simulaba no ser (una dictadura).

En cualquier caso y volviendo al tema general y principal en que estamos aquí, en dicha obra de 1966 — que ha sido básica en «mi filosofía jurídica y política»— yo resumía «las características generales que corresponden, como exigencias imprescindibles, a todo auténtico Estado de Derecho». Éstas, que después se explicitaban y ampliaban a lo largo del libro, eran verdaderamente lo contrario del régimen franquista. Eran tales notas las siguientes: «a) Imperio de la ley: ley como expresión de la voluntad general; b) Separación de poderes: legislativo, ejecutivo y judicial; c) Legalidad de la Administración: regulación por la ley y control judicial; d) Derechos y libertades fundamentales: garantía jurídico-formal y realización material».

Como se ve, en principio son substancialmente las mismas características que Atienza atribuye a un concepto de Constitución que es propio «en la época contemporánea» de un Estado constitucional. Seguiríamos, pues, con la identidad entre ambos modelos prescriptivos, el Estado de Derecho y el Estado constitucional. Pero hoy — para «tiempos recientes», apunta aquél— parece exigirse algo más: ¿tal vez «una Constitución extremadamente invasora», de la que después también se habla allí? En este caso habría que preguntar: ¿Es esta concepción de la Constitución la que trata de imponerse, subrayo, como doctrina única y de manera casi obsesiva en no pocas de las actuales miméticas y excluyentes apologías acríticas de la fórmula del Estado constitucional de Derecho? Y también ¿quién será el encargado de dirigir y llevar a cabo tal invasión, la «doctrina», el poder judicial? Recuérdese que la doctrina de algunos finos juristas ya ha encumbrado a los jueces nombrándoles los «señores del Derecho». Volveremos enseguida sobre estas y otras conexas cuestiones.

Por el momento yo querría únicamente llamar la atención (en relación con la necesaria, imprescindible, presencia de la Constitución) sobre otros breves pasajes de aquel viejo libro mío, trasunto por supuesto de lo que era teoría común en la mejor bibliografía europea de la época. Por un lado para señalar que, al hablar allí del imperio de la ley, de modo expreso ya se incluía siempre en ella a la Constitución (como, por lo demás no podía por menos de ser). Este era mi texto: «La ley ordinaria se conexiona y subordina a la ley fundamental (Constitución) y el control de constitucionalidad de las leyes asegura precisamente esa conexión y subordinación». Leyes y Constitución y esta, pues, como auténtica y básica norma jurídica. Por otro lado, unido a lo anterior, 
para afirmar la no omnipotencia pero sí «la primacía del poder legislativo, creador del Derecho, frente a los poderes ejecutivo y judicial, aplicadores del mismo: es decir, imperio de la ley. Y en ese contexto - es la principal pregunta que allí de modo expreso me formulaba - chabría base en este sistema para un absolutismo del legislativo, una falta de control y de limitación sobre la creación del Derecho realizada por el Parlamento? La respuesta debe ser evidentemente negativa: el poder legislativo está limitado por la Constitución y por los Tribunales, ordinarios o especiales según los sistemas, que velan por la garantía de la constitucionalidad de las leyes». Es decir, espacio para la legislación y para la Constitución no separados ni escindidos sino mucho más vinculados y coordinados, aunque en normativa subordinación.

Si el Estado de Derecho (democráticamente entendido, soberanía popular) es así imperio de la ley, resulta evidente que aquél es y habrá de ser por encima de ello imperio de la ley fundamental, imperio de la Constitución. Desde este punto de vista resulta obvio (casi tautológico) que todo Estado de Derecho sería — por utilizar la tan interiorista terminología hoy en uso-, además de Estado legislativo de Derecho, también, más arriba, Estado constitucional de Derecho. El poder legislativo, poder prevalente sobre el ejecutivo y el judicial en el ámbito del poder constituido, es y debe ser un poder a su vez subordinado a la Constitución. Para controlar motivadamente esto existen, con diferentes formas y poderes, los tribunales de efectos constitucionales: indicaría que mis preferencias sobre ello no están por el modelo norteamericano (jueces ordinarios, 1805) pero tampoco por el británico Westminster puro (Parlamento) sino más bien en la dirección de Canadá y, creo, Suecia (segundas lecturas legislativas, etc.). Sin olvidar que todos aquellos poderes — en cuanto poder constituido- están y deben así estar subordinados en última instancia al poder constituyente, supremo poder soberano, que es quien, por los procedimientos establecidos (de las exigencias éticas y políticas de otras vías se hablará después) podría asimismo comenzar por revisar y reformar la propia Constitución: mejor, por lo tanto, que esta no sea en exceso rígida (para el trasfondo teórico de estas cuestiones reenvío, entre otra bibliografía, al libro de Pedro de Vega, La reforma constitucional y la problemática del poder constituyente, 1985: ahí, entre otras cosas, el debate sobre el alcance de la «revisión total» que se establece en el art. 168 de nuestra Constitución).

Es verdad que en el pasado - en cualquier caso un pasado anterior al segundo decenio del siglo XX que ve la inicial consolidación del Estado de Derecho- se ha tendido a definir de manera no expresa pero sí de modo reductivo a la Constitución con un carácter meramente programático, es decir no prescriptivo, no (más o menos) directamente normativo. Frente a tales reducciones, el entendimiento de la Constitución como norma jurídica, con todas las mediaciones y reservas que la prudencia (incluso la jurisprudencia) autorice o permita introducir, me parece una conquista a todas luces muy positiva y por completo coherente con el mejor Estado de Derecho.

Los juristas, de todos modos, no deberían disminuir más allá de la cuenta (jurídica) esa significación y esa función, política y socialmente muy relevante, adjudicada y de hecho impulsada por las Constituciones en ese conflictivo pasado del siglo XIX y parte del Xx. La prueba indudable es lo mucho que se luchaba en esos tiempos por la Constitución, su tan emotiva simbología en el «inconsciente colectivo» (fiestas y plazas de la Constitución por doquier) y — señal muy decisiva— la prisa que se daban los enemigos 
de ella para, acá o allá, derogarla, destruirla o falsearla en cuanto podían. Un ejemplo eminente entre nosotros ha sido, en este sentido, la Constitución de Cádiz de 1812. Se dice ahora que en esas épocas (Estado legislativo) lo único o lo importante eran las leyes ( ¡alguno diría que lo realmente importante eran los reglamentos!) pero también lo eran, a pesar de todo, las Constituciones. Mayor aproximación, pues, entre legislación y Constitución, es lo que vengo subrayando o demandando en estas páginas. Sin excluir otras discrepancias, coincido no obstante con Ferrajoli en que ambas dimensiones forman parte del mismo amplio mundo común del positivismo jurídico: del mismo mundo metodológico y, yo diría, que también del mismo mundo histórico.

Todas estas puntualizaciones vienen aquí y ahora a cuento de mis fuertes reservas - asumido críticamente tal proceso histórico- frente a la, en nuestros días tan en auge, extremosa contraposición doctrinal que de modo esencialista (¿iusnaturalista?) quiere establecerse por algunos exégetas entre un casi perverso Estado legislativo de Derecho y un casi perfecto Estado constitucional de Derecho (entronizando éste, después aludiré asimismo a la interiorista suplantación que se propone por aquellos con respecto del Estado democrático de Derecho). En esa perspectiva se demonizaría al primero como producto espurio de los políticos (los parlamentarios) y de las mayorías y se deificaría al segundo como resultado excelso (con excelencia) de la obra hermenéutica de sabios minoritarios juristas.

Sin prescindir en términos concretos de la crítica, yo sin embargo por principio y por coherencia - como vengo diciendo- aproximaría mucho más ambas instancias, Constitución y legislación. La Constitución no debe ser apriorísticamente utilizada contra la legislación. En definitiva, la procedencia, la génesis, la raíz de una y otra no es tan radicalmente diferente u opuesta, (la soberanía popular), sin que con ello se niegue para nada, entre otras circunstancias, la superior calidad de la cantidad procedimental acogida en la Constitución. Es curioso e interesante recordar, por otro lado, cómo en aquellos años iniciales de nuestra transición a la democracia algunos actuales destacados (neo)constitucionalistas figuraban entonces entre los más escépticos o negadores de las cualidades y potencialidades del texto de 1978. Reenvío sobre ello a mi ensayo de 1998, Las ideologías de (sobre) la transición, después revisado y ampliado en mi libro Ética contra política. Los intelectuales y el poder (1990).

Para aquella concepción positiva (pero «no invasora») de la Constitución que hago mía, todo Estado de Derecho sería así, a la vez, Estado constitucional, legislativo, administrativo y judicial, de Derecho: son todas ellas dimensiones internas de tal tipo de ordenamiento jurídico (acerca de cómo mejor proteger unos u otros derechos fundamentales), dimensiones por lo demás no exentas de fuertes querellas entre sí y entre sus cultivadores y profesionales. Dentro de él, por supuesto, la Constitución es - en la perspectiva de la ciencia jurídica - la norma fundamental, a no confundir de todos modos, como ya vimos, con la kelseniana Grundnorm (de carácter lógico trascendental) con planteamientos que reenvían a la conexión entre Derecho y poder y -en la perspectiva de la filosofía jurídica - a la valoración crítica de ambos. La primera expresa ante todo la realidad del Derecho (el poder), la segunda su racionalidad (teoría de la justicia). Ésta implica ya su apertura externa a la consideración de qué, cuales sean, los derechos a proteger, así como de las condiciones sociales, económicas, políticas y culturales en que uno u otro Estado de Derecho se inserta: bien para su 
conservación o para su transformación desde las coherentes exigencias éticas de toda sociedad democrática con base siempre en la libre autonomía moral individual. Y esa perspectiva de teoría de la justicia habrá, pues, que diferenciar siempre - a pesar de todas sus dificultades - entre disvalores inicuos, para oponerse a ellos, y valores (más) justos procurando su progresiva implantación.

Quiero decir también con todo ello que el actual Estado constitucional de Derecho no debe (ni puede) contraponerse al denominado Estado legislativo de Derecho, ni ser entendido como sustitutorio sino como complementario interno del Estado democrático de Derecho. Pero esta es (im)precisamente la tesitura ambigua en que se mueve gran parte de la filosofía jurídico-política actual. Afirmada la superioridad, como norma fundamental, de la Constitución, me parece necesario insistir en que corresponde a la norma legal, al Derecho positivo creado por la representación de la soberanía popular (al Parlamento, pues, y no al poder judicial), la primera y principal interpretación, concreción y realización de aquélla. Imprescindible en este contexto - debería resultar obvio advertirlo - la crítica y autocrítica para la siempre abierta revisión y transformación de tal Derecho positivo, así como para la necesaria reforma y autentificación de las instituciones jurídico-políticas de la democracia deliberativa, participativa y representativa (Parlamento, partidos políticos, sistemas electorales, etc.) y, por lo tanto, del mismo Estado democrático de Derecho. Este, no se olvide, implica siempre la doble participación que caracteriza a la democracia: libre participación en las decisiones, igual participación en los resultados (en los derechos fundamentales).

Mis cautelas y mis advertencias críticas frente al mimético entusiasmo actual por la fórmula del Estado constitucional de Derecho surgen y aumentan a causa de una doble interrelacionada prevención: por un lado, en la medida — como digo- en que éste implique y favorezca una real infravaloración de las instituciones legislativas democráticas y, por otro (derivado de ahí), en cuanto que la interpretación y aplicación de los superiores principios y valores constitucionales pretendan atribuirse y reducirse de manera casi exclusiva o muy predominante a las meras instancias y criterios de los órganos judiciales. Entre estos y aquellos, imprescindibles los principios y los jueces, están y tienen que estar, con toda su fuerza y legitimidad, las normas legales (legislativo estatal nacional o, cada vez más, supranacional, Unión Europea y demás) que, entre otras cosas, aseguren en todos los órdenes un trato mucho más igual. El Parlamento - lo reitero- es, a mi juicio, el primer y prioritario interprete de la Constitución.

La invocación al Estado constitucional de Derecho de ningún modo puede servir como pretexto para puentear, obviar, al Estado legislativo de Derecho, ni —invocando «la aplicación directa de las normas constitucionales»— puede por tanto valer como disfraz ideológico para un reductivo Estado judicial de Derecho, poco acorde con la legalidad (incluida la constitucional) y la democrática legitimidad. En tal situación todos los conflictos y luchas políticas se trasladarían entonces (aún más) al interior del poder judicial. Para que quede bien claro todo lo anterior — así lo espero- recordaré que hace ya muchos años, defendiendo como hoy la función creadora (incluso alternativa) no de mera subsunción mecánica del juez, puse por escrito que a mi juicio donde mejor y de modo más coherente funciona una necesaria «magistratura democrática» es precisamente en el marco siempre abierto y crítico de una precedente legislatura democrática. Por cierto que, a propósito de estas cuestiones, vengo con frecuencia 
insistiendo, sin éxito hasta el momento, en lo interesante que será llevar a cabo una investigación, un análisis de fondo (tesis doctoral o estudio posdoctoral) de carácter comparativo - con sus pros y contras, con sus concordancias y divergencias-entre los modelos del «juez alternativo» (de ayer) y el «juez garantista» (de hoy).

\section{LA JUSTIFICACIÓN ÉTICA DE LA DEMOCRACIA. MAYORÍAS Y DERECHOS HUMANOS}

Pero el Estado de Derecho — aunque así lo parezca— no es sólo cosa de juristas, única y exclusivamente, una cuestión jurídica. En traslación de la vieja crítica al neopositivismo analítico, también diría yo aquí que hay más cosas en el cielo y en la tierra de las que se sueñan en la ciencia jurídica, aún más en la dogmática jurídica. No es ni real ni racional que el Derecho aparezca y permanezca solo, aislado, pretendidamente puro. Evitando la simplicidad de ciertos reduccionismos instrumentalistas, es verdad que el Derecho y el Estado se producen como medios pertinentes, pienso que imprescindibles, para un fin más esencial: en expresión bíblica, no se hizo el hombre para ellos, sino ellos para el hombre, para los seres humanos. Y a quienes en rigor más importa que aquel exista, funcione y sea real y formalmente respetado no es tanto - aunque también - a los gobernantes (así, en definitiva, más y mejor controlados) sino a los ciudadanos, a sus derechos, libertades y necesidades. Y muy especialmente les interesa - tendría que interesar- a aquellos que pueden protegerse menos, o nada, por sus propios medios, empezando por los de carácter económico. Como sugiere FOUCAULT, el poder no sabemos exactamente quién lo tiene, pero sí sabemos quién no lo tiene: la respuesta, con todo, no debe ser sólo sectorial, en red, sino también institucional, estatal.

Pero para que se produzca esa libre adhesión cívica, es necesario, requisito decisivo, que tales demandas, exigencias éticas y sociales, frente a las prepotencias públicas pero también privadas, se encuentren efectivamente reconocidas y garantizadas por el Estado de Derecho: por unas normas jurídicas, Constitución, leyes, decisiones administrativas y judiciales, que de verdad incorporen contenidos - prescripcionesconcordes con la protección y realización de tales derechos fundamentales. Estos, los derechos fundamentales, constituyen la razón de ser del Estado de Derecho, su finalidad más radical, el objetivo y criterio que da sentido a los mecanismos jurídicos y políticos que componen aquél. La democracia, doble participación es y debe ser —en ello he insistido aquí y también en otros escritos míos- además de participación en la toma de decisiones, demanda de participación en los resultados, es decir en derechos, libertades, necesidades.

El Estado de Derecho es la institucionalización jurídica de la democracia política, siempre entendida ésta, la democracia, como proceso abierto en el tiempo derivado de las instancias éticas de autonomía moral individual y de dignidad del ser humano como ser de fines. El Estado de Derecho, en esa su empírica y también racional vinculación e interrelación con la democracia, lo que hace es tratar de convertir en sistema de legalidad tal criterio de legitimidad: y en concreto, institucionaliza de uno u otro modo esa participación en decisiones y en resultados, es decir garantiza, protege y realiza (en 
una u otra medida según tiempos y espacios, historia y lugar) unos u otros derechos fundamentales: desde las libertades cívicas y las garantías penales a las de carácter social, económico y cultural para todos los ciudadanos y, con especial sensibilidad, también para las minorías y los agentes sin poder. Es ahí, en ese proceso histórico, donde se insertan los modelos del muy incipiente y discriminatorio Estado liberal y, posteriormente, del Estado social con muchas mayores cotas de igualdad. Junto con otras manifestaciones que en esa línea y con otros rótulos pudieran en el futuro configurarse, aquellas constituyen plurales fases, momentos, dimensiones, con muy diversas connotaciones e implicaciones, de lo que con exigentes razones podríamos en nuestro tiempo denominar y proponer prescriptivamente (utopía racional) como democracia y como Estado democrático de Derecho.

Pero la democracia, tal y como se viene resaltando aquí, no es pues algo que sólo tenga que ver con el mundo de la política. Menos aún, es aquella un exclusivo sistema de carácter técnico procedimental, que también lo es y tiene que serlo, aunque evitando siempre degradarse en simples reducciones economicistas y/o mercadistas de ella. Con frecuencia tales reducciones teóricas propician, por lo demás, fácticas corrupciones con el consiguiente descrédito de ella. Votar y elegir representantes y gobernantes - para la participación en la toma de decisiones-implica ya en democracia ineludible conexión y reenvío a valores éticos, la igual libertad como básico y central. Es preciso, pues, vincular, entroncar íntimamente ambas dimensiones, ética y procedimental, de la democracia: lo ético es aquí concomitante con lo procedimental. Correlación, pues, entre democracia como moral (en la cual en todo momento insistió desde esos valores nuestro José Luis Aranguren), democracia como política (imprescindible pero deficiente siempre de calidad sin aquélla) y democracia como institucionalización jurídica de las dos anteriores — principios éticos y exigencias políticas- en el Estado democrático de Derecho.

Derivada de la mejor Ilustración (KANT como gran punto de partida) y desarrollando las anteriores correlaciones, a) la ética hoy (la democracia como moral) es, ha de ser - en sus dos expresiones- primero autonomía individual en libertad pero también, como exigencia coherente, autorrealización personal (el ser humano como ser de fines), es decir autorrealización de todos los seres humanos sin exclusiones. Por su parte, b) la política, la democracia política, en cuanto legitimidad fundamental se identifica y se concreta de modo correlativo en una doble vertiente: como participación en (la formación y toma de) las decisiones y como participación en (la producción y distribución de) los resultados, medidos en términos de satisfacción de necesidades y de reconocimiento de derechos y libertades. Precisamente para tratar de asegurar tales exigencias éticas y políticas, $c$ ) el ordenamiento jurídico, la institucionalización jurídica de la democracia, el Estado de Derecho — como ya se ha señalado- lo que hace es legalizar, convertir en principio de legalidad, con la eficaz fuerza coactiva detrás, tales valores éticos (libertad-igualdad identificados en el valor justicia) y políticos (doble participación como síntesis del valor legitimidad).

El proceso de decisión democrática, y con él ese Derecho y ese Estado, es —como bien recordaba C. NiNO- el que más se identifica con el proceso de decisión ética (autonomía moral) y, a su vez, el que contiene en su interior mayor y mejor posibilidad para la actuación y realización efectiva de tales autonomías personales. En ese mismo 
mundo pero, en cierto modo, invirtiendo esa argumentación y primando el lado jurídico de la misma, el profesor F. LAPORTA entiende que las exigencias racionales del imperio de la ley, cuidadosamente analizadas por él en toda su complejidad, constituyen base ineludible para la propia autonomía personal, para una coherente teoría de la justicia y, por tanto, también para la posible potenciación de condiciones sociales progresivas derivadas de esos ilustrados valores éticos y políticos (El imperio de la ley: una visión actual, 2008).

Este sería, a mi juicio, el marco preferente para una filosofía jurídica (y política) actual con, entre otras aportaciones, esa sólida construcción del imperio de la ley, del Estado constitucional y de la legitimidad del Estado de Derecho, sobre la afirmación fundamental de la libertad crítica y la autonomía moral personal. En ella es donde — creo- deben plantearse y encontrarse vías válidas de buena orientación (difícil la total y exhaustiva resolución) para las que se consideran cuestiones-límite de aquella y de la propia filosofía moral. Las leyes en democracia, con libertad, las hacen en el Parlamento las mayorías (más o menos cualificadas y/o consensuadas): las que, a través del voto, han podido llegar a él y que, junto con las minorías, representan al conjunto de la sociedad. Y también las Constituciones - leyes supremas - se producen así, con aún mayores exigencias de consenso y participación (referéndum popular) y con mayor vocación de permanencia: limitan, además, las competencias legislativas parlamentarias, pero también impulsan y exigen — de esto se habla mucho menos- la acción positiva del legislador. Si, tras intentado el consenso, no se decidiese por mayorías, sencillamente se estaría dando a unas u otras minorías al poder de bloquear lo que incluso las grandes mayorías consideran justo y/o más conveniente. La cuestión —bien conocida pero no siempre bien planteada - sería entonces la siguiente: ¿son omnipotentes las mayorías, tanto las parlamentarias (ya vemos que no) como, sobre todo, las constitucionales, es decir las del poder constituyente a la hora de establecer, o reformar, una Constitución?

Es fácil, y en el fondo acertado, contestar que los derechos humanos constituyen hoy ese límite. Pero dicho así, sin más, sólo eso, resulta en exceso genérico e indefinido. Es verdad que la historia, las luchas históricas, y la razón crítica operando en ella, permiten en nuestros días establecer declaraciones de esos derechos (de ámbito nacional y trasnacional) con un amplísimo apoyo social y reconocimiento teóricamente casi universal: la prueba es como se esfuerzan los dictadores por camuflar sus violaciones (homenaje del vicio a la virtud). Tales declaraciones, además, por lo general se insertan dentro del propio texto constitucional, con lo cual tal límite se convierte así en autolimitación establecida por la misma Constitución. ¿Quedaría, pues, todo ello rígidamente blindado, una zona que resultaría ser intocable e inmutable (si bien, como Derecho positivo de origen democrático, muy distinto del tradicional modelo iusnaturalista), contra las libres y justas aspiraciones y decisiones, por ejemplo de generaciones posteriores, que mayoritariamente postularan un nuevo poder constituyente?

Otro interrogante podría plantearse incluso — situación límite pero nada irreal (entre otros ejemplos, Portugal, países del este de Europa o algunos de Latinoamérica)—, para, por razones de total incompatibilidad, cambiar de Constitución sin someterse a los procedimientos establecidos en la anterior. Estos casos son los que, con KELSEN, se podrían calificar jurídicamente de revolución (no necesariamente violenta) 
o de ruptura pacífica. En la transición española, tras la dictadura franquista, si no hubiese habido la «Ley de reforma política», se habría actuado así para lograr la democracia y, por supuesto, hubiese sido legítimo (aunque quizás más costoso) hacerlo. ¿Cuáles son los modos de proceder en tal situación? Fácticamente, ya lo sabemos, con algún tipo de suficiente apoyo social y con el poder efectivo para hacerlo. Ese hecho - recordemos - crea el nuevo Derecho, la nueva Constitución. Así es, pues, como ocurre de hecho con toda su complejidad, pero ¿cómo justificarlo o rechazarlo (ello no es nada inocuo) desde el punto de vista moral y también desde el punto de vista de la legitimidad democrática? De eso precisamente es de lo que se está tratando en estas páginas.

Ahora bien, junto a estos supuestos de sobrevenidas intervenciones para el cambio constitucional (mayorías posteriores versus mayorías anteriores, pero también legitimidades posteriores versus legitimidades anteriores), lo que hay que plantear aquí con carácter general, incluso en las situaciones de la mayor normalidad, es el fundamento último de las tales decisiones mayoritarias, es decir en el fondo la justificación ética de la democracia. Reconozcamos la superior entidad y calidad de la Constitución como norma suprema del ordenamiento jurídico, su carácter referencial como impulso y, a la vez, límite de la legislación; también la hipotética (necesaria) obediencia a ella si se quiere que las otras normas tengan validez y que los actos de los concretos ciudadanos valgan jurídicamente, pero asimismo la consideración de los valores éticos y políticos que incorpora y hace efectivos como Estado constitucional (Estado de Derecho). Con todo ello habría, no obstante, base para preguntar: ¿Es que acaso son ya siempre infalibles, perfectos o, mejor aún, completamente justos los preceptos - todos y cada uno- de la Constitución incluso por muy democrática que sea? ¿Es la Constitución la última palabra? Jurídicamente así es, pero puede no serlo (o no del todo) desde el punto de vista moral (ético). ¿Pueden, pues desde esa óptica más radical, equivocarse las mayorías?

Por supuesto que las mayorías —aludo tanto a las mayorías parlamentarias como a las constitucionales — pueden equivocarse y corromperse: o ser engañadas, manipuladas y corrompidas: ¿en qué medida no lo son desde, por ejemplo, la poderosa conjunción de los poderes económicos y mediáticos?; pero también pueden equivocarse y corromperse las minorías; y ino digamos el individuo por excepcional que sea, o parezca ser! Pero en democracia — y en cualquier otro aspecto de la realidad- hay que trabajar con este material: así somos, ni totalmente egoístas ni totalmente altruistas, aunque todos estaríamos de acuerdo - creo- en que hay que favorecer y potenciar al máximo (derechos humanos) esta nuestra segunda positiva condición. Obvio que la ilustración, la deliberación y la educación ciudadana coadyuvan fuertemente a ello. Pero esos son los riesgos y las ventajas (las miserias y las grandezas) de la decisión democrática adoptada por la regla de las mayorías. Hasta para decidir que se prefiere adoptar otro modo de tomar decisiones y de designar dirigentes o representantes (sorteo, etnia, edad, género, etc.) pienso que habría de hacerse libremente a través de esa (meta) regla mayoritaria de decisión: al menos así tendrá que ser si se quiere seguir argumentando y operando - como estamos haciendo aquí- dentro del mundo de la democracia (reenvío, de todos modos, para otras implicaciones y dimensiones de esta debatida cuestión, al viejo libro de N. BobBio, C. OfFE y S. Lombardini, Democracia, 
maggioranza e minoranze, 1981, así como a los últimos trabajos de A. RUIZ MigUEL sobre Decisión y de R. VARGAS MACHUCA sobre Representación, ambos incluidos en la obra colectiva de A. ARTETA como editor, El saber del ciudadano. Las nociones capitales de la democracia, 2008).

Lo decisivo — -seguimos adelante en esta indagación — es que la ley de las mayorías siempre ha de respetar (como por definición interna de ella misma es coherentemente exigible) la libre crítica proveniente de esas dos mencionadas instancias: la individual, último refugio de la libertad, y, sin esencialismos transpersonalistas, la que pueda derivarse de unos u otros grupos minoritarios (minorías por razón de edad, sexo, etnia, etc.). Sin el reconocimiento de esa libertad individual y de la consiguiente acción de ella en las minorías, las mayorías no pueden probar que efectivamente son mayorías, ni pueden legitimarse como tal. Las mayorías sólo saben que lo son (sólo saben que son mayoría) cuando está permitida — como es obligada exigencia — la libre expresión (y participación) que deriva en última y más radical instancia del valor de la autonomía moral personal. En definitiva, sin sufragio libre y universal las mayorías no pueden probar que lo son: ahí (con J. MugUERZA) el valor hasta integrador del disenso.

El respeto, pues, a la libertad crítica, con todo lo que supone de respeto a la persona, a su dignidad, a su libertad de pensamiento y de expresión, con el reconocimiento del derecho a una efectiva participación política de todos los ciudadanos constituye la base ética y política de la democracia. Así pues en lugar sin más de «límites»o «limitaciones» de la democracia, yo —en la indagación de su último fundamento- preferiría hablar de exigencias coherentes o, mejor de imperativos de coherencia con los mismos principios éticos y políticos que definen y justifican a las democracias (he insistido en estos mismos principios en otras obras mías de hace ya bastantes años; y últimamente en contumaz diálogo con el gran amigo E. GARZÓN VALDÉs, en mi nota Entrada libre en el «coto vedado», Doxa, 30, 2007).

Es cierto que esa libertad crítica (conciencia moral y autonomía personal) es, por de pronto, desde la perspectiva de la «libertad negativa» (I. BERLIN) el valor límite para las determinaciones mayoritarias tanto de la legislación ordinaria como de la propia Constitución: lo que éstas no pueden de ningún modo negar y suprimir —ni interferir o reducir según los casos y para su correlativa protección en los demás- si aquéllas pretenden legitimarse como reglas democráticas de decisión mayoritaria. Resulta, pues, imprescindible esa legítima concepción negativa como límite que impide la ilegítima invasión de las mayorías - insisto, tanto legislativas como constitucionales- en el ámbito irrenunciable de la intimidad, de la libertad personal que a todos corresponde. Los casos de conflicto — también entre ética privada y ética pública一 no serán siempre fáciles de resolver, aunque tampoco faltan ni medios ni reglas para ello. Pero, junto a tal concepción de la libertad negativa, yo aquí resaltaría algo que me parece decisivo y diferenciador: que a mi juicio esa afirmación de la autonomía moral personal y de la libertad crítica — que definen a la condición humana-implica y exige a su vez de manera muy principal una concepción positiva y creadora de ellas (libertad positiva, que I. BERLín subordina a la anterior). Y aquí es donde me parece que esa básica y definitoria autonomía moral individual, libertad crítica y autodeterminación personal se manifiestan con toda plenitud como el hecho y, a su vez, el valor básico y fundamental. 
Sin libertad no hay nada: ni igualdad, ni justicia, ni dignidad, ni auténtica paz. Incluso decidir que en el futuro uno no quiere decidir por sí mismo (entregándose a los dictados de los demás o de alguien que carismáticamente considera excepcional), es algo que previa y necesariamente uno mismo hace tras una libre decisión. Es decir, decide (ahora) libremente que no quiere (después) decidir libremente. Pero a escala colectiva, democrática, ello exigiría tener que seguir siempre contando en el futuro y periódicamente (casi a diario) con la libre y crítica decisión de los nuevos ciudadanos. Desde esos presupuestos, la regla de las mayorías, la misma soberanía popular y hasta la consecuente democracia encuentran — creo- su más firme fundamento y justificación en tal autonomía moral personal, en la libertad crítica para decidir. Con razón decía KANT que esta libertad de pensamiento, de opinión y de expresión, constituye el más auténtico (incluso único) derecho humano en su sentido más radical.

La libertad crítica se muestra aquí por tanto — así al menos la veo yo- con ese carácter positivo y creador. En la historia también ha operado de ese modo: se pugnaba (y está bien) por lograr la no interferencia procedente de gentes individuales y de unos u otros poderes privados y públicos (Estados, Iglesias) en la vida propia de cada cual. Pero a su vez - libertad positiva que yo considero, a diferencia de B. CONSTANT y quizás de parte de la opinión general, como la «libertad de los modernos»- se entendía con toda claridad que aquella no se podría conseguir si la tal libertad crítica para decidir y participar no se asumía por cada uno y por todos para formar la soberanía popular y así legislar y proceder a una coherente organización de la sociedad en beneficio general. Todo ello - insisto- procedía precisamente de esa creencia positiva en la razón y en la voluntad como factores determinantes de la vida personal y —con las necesarias mediaciones - también de la vida colectiva (Estado y Derecho) en democracia y libertad. En otros términos, quizás más de filosofía política y en relación con mi concepción de la democracia como doble participación: que sin participación (libre) en las decisiones (libertad positiva) no hay participación (justa) en los resultados, derechos y necesidades, porque todos, poderes públicos y privados, tienden siempre a interferir en los demás buscando el beneficio propio (reduciendo o anulando la, mal denominada libertad negativa).

Esa es la raíz, el «núcleo duro», de los derechos humanos que derivan de ella en esos mencionados ámbitos de participación: la autonomía, la libertad crítica personal, la libertad de pensamiento y de expresión, siempre en libertad. Y la vida misma, se dirá, porque si no se vive todo esto carece de sentido y significación: pero, a su vez, vida personal en las condiciones sociales, económicas y culturales que derivan de la dignidad humana. Desde ahí, pues, los derechos humanos como conquistas (luchas) de la historia y la razón, acompañadas siempre de las adecuadas instituciones que los hagan realidad. Este es, debe ser, creo, el objetivo fundamental de estas nuestras creaciones teóricas (de filosofía moral, política y jurídica) que son en nuestros días el Estado constitucional y, con mayor complejidad, el Estado social y democrático de Derecho. 